\title{
Correction to: Impact of cigarette butts on bacterial community structure in soil
}

\author{
Elizaveta Koroleva ${ }^{1} \cdot$ Aza Zizipo Mqulwa $^{1} \cdot$ Scott Norris-Jones $^{1} \cdot$ Sidney Reed ${ }^{1} \cdot$ Zahraa Tambe $^{1}$. \\ Aiden Visagie ${ }^{1} \cdot$ Karin Jacobs $^{1}$ (D) \\ Published online: 10 April 2021 \\ (C) Springer-Verlag GmbH Germany, part of Springer Nature 2021
}

\section{Correction to: Environmental Science and Pollution Research https://doi.org/10.1007/s11356-021-13152-w}

The correct captions of Figures 2 and 3 is shown in this paper.

Fig. 2 Non-metric multidimensional scaling (NMDS) plot showing the beta diversity of the samples, before and after treatment was applied, based on the Automated Ribosomal Intergenic Spacer Analysis (ARISA) profiles (stress value: 0.0524). B 1-3, biodegradable cigarette treatment; C 1-3, control treatment; $\mathrm{N} 1-3$, non-biodegradable treatment

Fig. 3 a Shannon indices $(\mathrm{H})$ before and after treatment with cigarette butt leachate. $b$ Simpson indices (D) before and after treatment with cigarette butt leachate

The original article has been corrected.

Publisher's note Springer Nature remains neutral with regard to jurisdictional claims in published maps and institutional affiliations.

The online version of the original article can be found at https://doi.org/ 10.1007/s11356-021-13152-w

Karin Jacobs

kj@sun.ac.za

1 Department of Microbiology, Stellenbosch University, Private Bag $\mathrm{X} 1$, Stellenbosch, South Africa 